\title{
Prediction of Nitrogen Responses of Corn by Soil Nitrogen Mineralization Indicators
}

\author{
R.R. Simard ${ }^{1, *}$, N. Ziadi ${ }^{2}$, M.C. Nolin ${ }^{2}$, and \\ A.N. Cambouris ${ }^{2}$ \\ ${ }^{1}$ Soil Science Department, University of Manitoba, 362 Ellis Building, \\ Winnipeg, Manitoba, Canada, R3T 2N2; '2Soils and Crops Research \\ Centre, Agriculture and Agri-Food Canada, 2560 Hochelaga Blvd, \\ Ste-Foy, Quebec, Canada, G1V 2J3
}

Soil nitrogen mineralization potential $\left(\mathrm{N}_{\min }\right)$ has to be spatially quantified to enable farmers to vary $\mathrm{N}$ fertilizer rates, optimize crop yields, and minimize $\mathrm{N}$ transfer from soils to the environment. The study objectives were to assess the spatial variability in soil $\mathrm{N}_{\min }$ potential based on clay and organic matter (OM) contents and the impact of grouping soils using these criteria on corn grain (Zea mays L.) yield, $\mathrm{N}$ uptake response curves to $\mathrm{N}$ fertilizer, and soil residual $\mathrm{N}$. Four indicators were used: OM content and three equations involving $\mathrm{OM}$ and clay content. The study was conducted on a 15-ha field near Montreal, Quebec, Canada. In the spring 2000 , soil samples $(n=150)$ were collected on a $30-\times 30-\mathrm{m}$ grid and six rates of $\mathrm{N}$ fertilizer ( 0 to $250 \mathrm{~kg} \mathrm{~N} \mathrm{ha}^{-1}$ ) were applied. Kriged maps of particle size showed areas of clay, clay loam, and fine sandy loam soils. The $\mathbf{N}_{\min }$ indicators were spatially structured but soil nitrate $\left(\mathrm{NO}_{3}{ }^{-}\right)$was not. The $\mathrm{N}$ fertilizer rate to reach maximum grain yield $\left(\mathrm{N}_{\max }\right)$, as estimated by a quadratic model, varied among textural classes and $\mathrm{N}_{\min }$ indicators, and ranged from 159 to $250 \mathrm{~kg} \mathrm{~N} \mathrm{ha}^{-1}$. The proportion of variability $\left(\mathbf{R}^{2}\right)$ and the standard error of the estimate (SE) varied among textural groups and $\mathbf{N}_{\min }$ indicators. The $\mathbf{R}^{2}$ ranged from 0.53 to 0.91 and the SE from 0.13 to 1.62 . Corn grain $\mathrm{N}$ uptake was significantly affected by $\mathrm{N}$ fertilizer and the pattern of response differed with soil texture. For the $50 \mathrm{~kg} \mathrm{~N} \mathrm{ha}^{-1}$ rate, the apparent $\mathbf{N}_{\min }$ potential (ANM) was significantly larger in the clay loam $\left(122 \mathrm{~kg} \mathrm{ha}^{-1}\right)$ than in the fine sandy loam $\left(80 \mathrm{~kg} \mathrm{ha}^{-1}\right)$ or clay $\left(64 \mathrm{~kg} \mathrm{ha}^{-1}\right)$ soils. The fall soil residual $\mathbf{N}$ was not affected by $\mathbf{N}$ fertlizer inputs. Textural classes can be used to predict $\mathrm{N}_{\max }$. The $\mathrm{N}_{\min }$ indicators may also assist the variable rate $\mathrm{N}$ fertilizer inputs for corn production.

KEY WORDS: soil $\mathrm{N}$ mineralization potential, $\mathrm{N}$ rate to reach maximum corn grain yield, corn, spatial variability, nitrogen use in agricultural fertilization, environmental indicators, precision agriculture

DOMAINS: agronomy, ecosystems management, environmental modelling, environmental monitoring, soil systems

\section{INTRODUCTION}

The prediction of the soil nitrogen mineralization potential $\left(\mathrm{N}_{\min }\right)$ in space and time in cool and humid climates is unreliable[1]. The soil $\mathrm{N}$ contents as evaluated by chemical extraction (e.g., $\mathrm{KCl}$ ) show short-range variation and often poor spatial dependence[2]. Good estimates of $\mathrm{N}_{\min }$ are necessary to minimize $\mathrm{N}$ transfer to the environment, to design better fertilizer $\mathrm{N}$ recommendations, and improve $\mathrm{N}$ management in the crop-soil system[3]. Studies conducted in Quebec on corn reported that fertilizer $\mathrm{N}$ recoveries vary between 40 to $65 \%$ of applied $\mathrm{N}[4,5]$. The nitrate $\left(\mathrm{NO}_{3}{ }^{-}\right)$concentration in the tributaries of the St. Lawrence is increasing[6] and $41 \%$ of the farmland area is intermediate to high risk of water contamination by $\mathrm{N}$ [7]. It is therefore important to achieve a good prediction of $\mathrm{N}_{\min }$ to minimize the risk of $\mathrm{N}$ transfer in corn production.

Prediction of $\mathrm{N}_{\text {min }}$ may be achieved by integrating fairly static soil attributes such as organic matter (OM) and clay contents[8]. These attributes are spatially dependent in the St. Lawrence lowlands $[9,10]$. The prediction of fertilizer $\mathrm{N}$ needs by $\mathrm{N}_{\text {min }}$ indica- 
tors can be used with Precision Agriculture (PA) technologies to define optimal $\mathrm{N}$ management strategies for corn.

Small plot research indicated that soil $\mathrm{N}_{\min }$ in cool and humid climates may be influenced by previous crop, soil mineral $\mathrm{N}$ content in spring, tillage system, landform, and soil drainage[3]. However, OM and soil $\mathrm{N}$ content remain key parameters in predicting $\mathrm{N}$ fertilizer needs[8,11]. The organic $\mathrm{N}$ pool in arable soils tends to be related to their clay content [5]. Until recently, in central Canada, $\mathrm{N}$ fertilizer application for corn was uniform[12,13] despite high within-field variability in crop $\mathrm{N}$ uptake[10,14]. Site-specific fertilizer N may increase crop yields and reduce residual soil $\mathrm{N}$ and subsequent leaching[15]. The objectives of our study were to (1) evaluate the spatial variability of the potential of $\mathrm{N}_{\text {min }}$ based on clay and OM contents and (2) evaluate the impact of grouping soils using these criteria on corn grain yield, grain $\mathrm{N}$ uptake response curves to $\mathrm{N}$ fertilizer, and soil residual $\mathrm{N}$.

\section{MATERIAL AND METHODS}

\section{Site Description}

A 15-ha plot $(270 \times 555 \mathrm{~m})$, part of a 34 -ha field located in St. Marc-sur-Richelieu, near Montreal, province of Quebec, Canada, was selected for this study. Mean annual precipitation is around $1000 \mathrm{~mm}$ and near 2700 corn heat units are available in the growing season. An intensive soil survey (scale 1:7500) was conducted in 1997. Seven soil mapping units (eight polygons) were delineated (Fig. 1) and five soil series formed on clay and alluvium deposits were identified: Saint-Urbain (very-fine clayey, mixed, mesic Typic Humaquept), Providence (very-fine clayey, mixed, mesic Aeric Humaquept), Du Jour (fine-clayey, mixed, mesic Aeric Humaquept), Du Contour (coarse-loamy over clayey, mixed, mesic Humic Endoaquept), and Latour (coarse-loamy over clayey, mixed, mesic Aquic Dystrochrept). Drainage conditions range from imperfect to very poor.

\section{Crop Management Information}

The studied field is under a corn-soybean rotation. Starter fertilizer was $15 \mathrm{~kg} \mathrm{~N} \mathrm{ha}^{-1}$ applied as 18-46-0 on May 17, 2000. The treatments consisted of six rates of $\mathrm{N}(0,50,100,150,200$, and $250 \mathrm{~kg} \mathrm{~N} \mathrm{ha}^{-1}$ ) applied as anhydrous ammonia on July 5, 2000. The treatments were distributed in a randomized complete block design with five replicates for 30 plots of 9 -m wide $\times 555-\mathrm{m}$ long. Corn was harvested in November $7^{\text {th }}, 2000$ at each sampling point from a $5-\times 0.75-\mathrm{m}$ area to determine entire above ground biomass. Only corn grain yield adjusted to $14 \%$ moisture content was presented in this study.

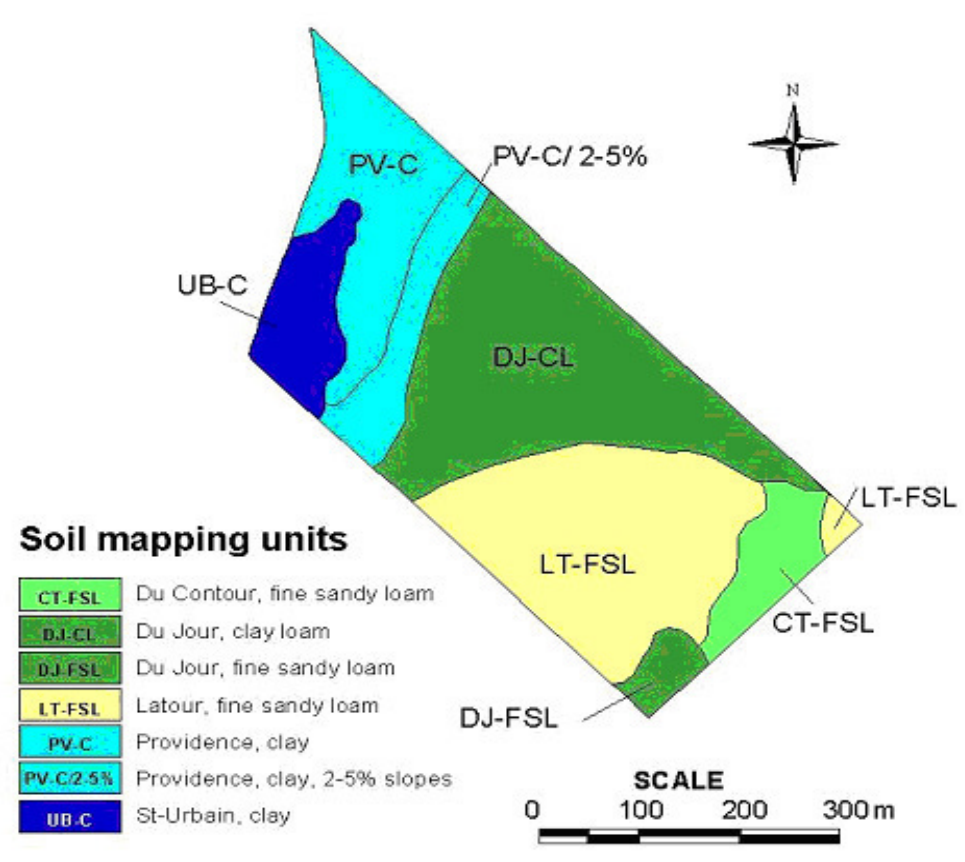

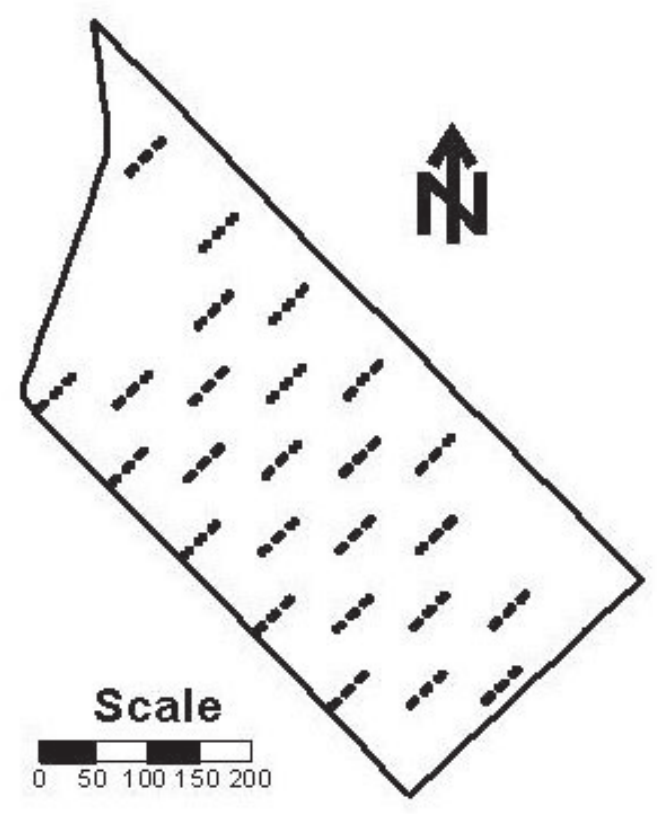

A

FIGURE 1. Maps showing (A) soil mapping units and (B) sampling design $(n=150)$ of the experimental plot. 


\section{Soil Sampling Strategy}

In April 2000, a stratified systematic soil sampling $(\mathrm{n}=150)$ was superimposed on the experimental design. Each block of six strips was positioned to cross the soil mapping units. In each strip, five subsamples were systematically taken on a 100-m interval using a triangular grid design between blocks to obtain 150 sampling grid points ( 30 plots $* 5$ subsamples). At each sampling point (n $=150$ ), four cores (one in each quadrant of a 1.5 -m radius circle), 0.2-m deep, were compounded to obtain a representative sample. Additional sampling points (50) located within and outside the experimental plot were used to improve the interpolation by kriging.

\section{Soil Analysis}

Samples were air dried, ground to $<2 \mathrm{~mm}$, sieved, and analyzed for the selected chemical and physical properties. Soil $\mathrm{pH}$ was measured in distilled water with a 1:2 soil:solution ratio. OM content was determined by wet oxidation[16]. Particle size analysis was carried out by the hydrometer method after organic matter oxidation[17]. The soil $\mathrm{NO}_{3}-\mathrm{N}$ and $\mathrm{NH}_{4}-\mathrm{N}$ contents were extracted in $2 \mathrm{M} \mathrm{KCl}$ with a 1:10 soil:solution ratio[18]. The $\mathrm{NO}_{3}-\mathrm{N}$ in the extracts was measured using a Dionex 4000i liquid chromatograph equipped with Ion Pack CG5 and CS5 columns (Dionex Corp., Sunnyvale, $\mathrm{CA}$ ), whereas $\mathrm{NH}_{4}-\mathrm{N}$ was determined colorimetrically by the indophenol blue method[18].

\section{Data Analysis}

Descriptive statistics and regression analysis were calculated using SAS[19]. Geostatistical analysis (semivariance and block kriging) were performed using $\mathrm{GS}^{+}[20]$ and kriged maps were produced with Surfer[21]. Analysis of variance on the effects of $\mathrm{N}$ fertilizer on corn grain yield and $\mathrm{N}$ uptake and on soil residual $\mathrm{N}$ was performed using the GLM procedure of SAS[19]. The $\mathrm{N}$ fertilizer rate $\left(\mathrm{N}_{\max }\right)$ required to reach the maximum corn grain yield was estimated by a quadratic model and four $\mathrm{N}_{\min }$ indicators as follows:

$$
\Delta \mathrm{Y}=\mathrm{a}+\mathrm{bX}+\mathrm{c} \mathrm{X}^{2}
$$

where DY is corn grain yield (yield at a given $\mathrm{N}$ rate applied yield with no $\mathrm{N}$ applied) in $\mathrm{Mg} \mathrm{ha}^{-1}, \mathrm{X}$ the $\mathrm{N}$ fertilizer rate $\left(\mathrm{kg} \mathrm{ha}^{-1}\right)$, and $\mathrm{a}, \mathrm{b}$, and $\mathrm{c}$ are regression constants. The $\mathrm{N}_{\max }$ was estimated by setting the first partial derivative of the $\mathrm{N}$ response curve equal to zero:

$$
\mathrm{d} \Delta \mathrm{Y} / \mathrm{dX}=\mathrm{b}+2 \mathrm{cX}=0
$$

and solving for $\mathrm{X}$. Therefore, $\mathrm{N}_{\max }\left(\mathrm{kg} \mathrm{N} \mathrm{ha}^{-1}\right)$ is calculated as:

$$
\mathrm{N}_{\max }=-\mathrm{b} / 2 \mathrm{c}
$$

The $\mathrm{N}_{\max }$ was not estimated when c was positive. When $\mathrm{N}_{\max }$ was $>250 \mathrm{~kg} \mathrm{ha}^{-1}, 250 \mathrm{~kg} \mathrm{ha}^{-1}$ were used[22]. The coefficient of determination $\left(\mathrm{R}^{2}\right)$ and the standard error of the estimate (SE) were used to determine $\mathrm{N}_{\max }$ in each soil class using $\mathrm{OM}$ and three equations involving $\mathrm{OM}\left(\mathrm{g} \mathrm{kg}^{-1}\right)$ and clay content $\left(\mathrm{g} \mathrm{kg}^{-1}\right)$ as $\mathrm{N}_{\text {min }}$ indicators. Three soil OM classes were thus obtained[23]: $\mathrm{OM} \leq 25,25<\mathrm{OM}<35$, and $\mathrm{OM} \geq 35$. The three following equations[10] were used to arbitrarily define three classes as follows:

$$
\begin{aligned}
\mathrm{N}_{\min 1}\left(\mathrm{~kg} \mathrm{ha}^{-1}\right)= & 4.00+0.29 \mathrm{OM}+0.22 \text { clay; } \\
& \mathrm{N}_{\min 1} \leq 50,50<\mathrm{N}_{\min 1}<100, \text { and } \mathrm{N}_{\min 1} \geq 100 . \\
\mathrm{N}_{\min 2}\left(\mathrm{~kg} \mathrm{ha}^{-1}\right)= & 22.16+1.91 \mathrm{OM} ; \\
& \mathrm{N}_{\min 2} \leq 70,70<\mathrm{N}_{\min 2}<90, \text { and } \mathrm{N}_{\min 2} \geq 90 . \\
\mathrm{N}_{\text {min3 }}\left(\mathrm{kg} \mathrm{ha}^{-1}\right)= & 18.62+1.46 \mathrm{OM}+0.10 \text { clay; } \\
& \mathrm{N}_{\text {min3 }} \leq 70,70<\mathrm{N}_{\text {min3 }}<100 \text {, and } \mathrm{N}_{\text {min } 3} \geq 100 .
\end{aligned}
$$

An apparent $\mathrm{N}_{\min }$ coefficient (ANM) was also calculated as follows: ANM $\left(\mathrm{kg} \mathrm{ha}^{-1}\right)=($ Corn grain $\mathrm{N}$ uptake $+[$ Fall soil $\mathrm{N}$ Spring soil N] - Fertilizer N added); N uptake was calculated by multiplying corn grain yield by its $\mathrm{N}$ concentration.

An apparent $\mathrm{N}$ recovery coefficient $\left(\mathrm{N}_{\mathrm{rec}}\right)$ was calculated as: $\mathrm{N}_{\text {rec }}(\%)=($ Corn grain $\mathrm{N}$ uptake from a $\mathrm{N}$ fertilizer treatment $-\mathrm{N}$ uptake from the control)* $100 /$ Fertlizer $\mathrm{N}$ added.

\section{RESULTS AND DISCUSSION}

\section{Within-Field Spatial Variability}

Within-field variability of soil attributes (Table 1) is larger than reported for other intensively sampled fields from the St-Lawrence Lowlands[9,10]. This may be related to different soil types developed from contrasting parent materials (marine clay and loamy alluvium) and drainage classes. Kriged maps of particle size showed three soil classes: clay, clay loam, and fine sandy loam soils. Clay content ranges from 104 to $586 \mathrm{~g} \mathrm{~kg}^{-1}(\mathrm{CV}=52 \%)$ and sand from 27 to $724 \mathrm{~g} \mathrm{~kg}^{-1}(\mathrm{CV}=45 \%)$. The OM content is moderately variable $(\mathrm{CV}=22 \%)$ ranging from 16 to $57 \mathrm{~g} \mathrm{~kg}^{-1}$. $\mathrm{N}_{\min 1}$ is more variable $(\mathrm{CV}=45 \%)$ than $\mathrm{N}_{\min 2}(\mathrm{CV}=16 \%)$ or $\mathrm{N}_{\min 3}(\mathrm{CV}=22 \%)$. The $\mathrm{N}_{\min 3}$ estimates a higher mean soil $\mathrm{N}$ mineralization than $\mathrm{N}_{\min 2}$ and $\mathrm{N}_{\min 1}$.

Isotropic semivariograms were computed to assess the within-field spatial continuity in $\mathrm{N}_{\min }$ indicators: clay, $\mathrm{OM}, \mathrm{NH}_{4}^{+}$, $\mathrm{NO}_{3}^{-}$, and $\mathrm{N}_{\text {min } 1}$ to $\mathrm{N}_{\min 3}$. Spherical models were most often selected (Table 2$)$. The semivariograms show very good fits $\left(\mathrm{R}^{2}>\right.$ 0.90 ) with isotropic models and relatively low residual sums of squares (data not shown). All variables except for $\mathrm{NO}_{3}{ }^{-}$show high $C / C_{0}+C$ ratios $(>0.75)$ indicating that the structured variance $(C)$ is a high proportion of the total variation (sill).

This suggests that the sampling strategy precisely and reliably modeled the spatial variability. However, the short-range variability in $\mathrm{NO}_{3}{ }^{-}$content indicates that a finer grid size is necessary to model its spatial distribution. This is confirmed by the cross-validation analysis (CVA) (Table 2). The indicators of soil $\mathrm{N}_{\text {min }}$ based on clay content (clay, $\mathrm{N}_{\text {min } 1}$, and $\mathrm{N}_{\text {min } 3}$ ) show higher $\mathrm{R}^{2}$ from the CVA than those derived from $\mathrm{OM}\left(\mathrm{OM}\right.$ and $\left.\mathrm{N}_{\min 2}\right)$. The $\mathrm{NH}_{4}{ }^{+}$has a higher $\mathrm{R}^{2}$ than $\mathrm{NO}_{3}{ }^{-}$which is particularly very low (0.20). The range $\left(A_{0}\right)$, the maximum distance over which properties remain spatially correlated, is quite small (42 to $100 \mathrm{~m}$ ) for all indicators, which suggest that a more intensive soil sampling than the $100-\times 100-\mathrm{m}$ grid common to commercial survey programs is needed to reliably estimate these $\mathrm{N}_{\min }$ indicators in this field. The soil $\mathrm{NO}_{3}{ }^{-}$content, commonly used for $\mathrm{N}$ fertilizer pre- 
TABLE 1

Statistical Description of Some Physico-Chemical

Properties of the $0-$ to $20-\mathrm{cm}$ Soil Layer of the

Experimental Field at the Beginning of the Study $(n=150)$

\begin{tabular}{lccc}
\hline Variable & Mean & Range & CV (\%) \\
\hline Sand $\left(\mathrm{g} \mathrm{kg}^{-1}\right)$ & 467 & $27-724$ & 45 \\
Silt $\left(\mathrm{g} \mathrm{kg}^{-1}\right)$ & 259 & $163-414$ & 27 \\
Clay $\left(\mathrm{g} \mathrm{kg}^{-1}\right)$ & 274 & $104-586$ & 52 \\
$\mathrm{OM}\left(\mathrm{g} \mathrm{kg}^{-1}\right)$ & 29 & $16-57$ & 22 \\
$\mathrm{NO}_{3}^{-}$spring $\left(\mathrm{kg} \mathrm{ha}^{-1}\right)$ & 83 & $13-210$ & 16 \\
$\mathrm{NO}_{3}^{-}$fall $\left(\mathrm{kg} \mathrm{ha}^{-1}\right)$ & 164 & $64-304$ & 23 \\
$\mathrm{~N}_{\text {min }}\left(\mathrm{kg} \mathrm{ha}^{-1}\right)$ & 74 & $35-145$ & 45 \\
$\mathrm{~N}_{\text {min2 }}\left(\mathrm{kg} \mathrm{ha}^{-1}\right)$ & 77 & $52-131$ & 16 \\
$\mathrm{~N}_{\text {min3 }}\left(\mathrm{kg} \mathrm{ha}^{-1}\right)$ & 88 & $63-140$ & 22 \\
\hline
\end{tabular}

TABLE 2

Geostatistical Parameters

\begin{tabular}{lccccc}
\hline Variable & Model & $\begin{array}{c}\text { Ratio* } \\
\mathbf{C} / \mathbf{C}_{\mathbf{0}}+\mathbf{C}\end{array}$ & $\begin{array}{c}\text { Range } \\
\mathbf{A}_{\mathbf{0}} \mathbf{( m )}\end{array}$ & $\begin{array}{c}\text { Model fits } \\
\left.\mathbf{( R}^{2}\right)\end{array}$ & $\begin{array}{c}\text { Cross- } \\
\text { Validation } \mathbf{( R}^{2} \mathbf{)}\end{array}$ \\
\hline Clay & Spherical & 1.00 & 57 & 0.94 & 0.95 \\
$\mathrm{OM}$ & Spherical & 0.88 & 72 & 0.95 & 0.66 \\
$\mathrm{NH}_{4}{ }^{+}$ & Spherical & 0.76 & 80 & 0.99 & 0.81 \\
$\mathrm{NO}_{3}{ }^{-}$ & Exponential & 0.50 & $44^{\star *}$ & 0.92 & 0.20 \\
$\mathrm{~N}_{\text {min1 }}$ & Exponential & 1.00 & $42^{* \star}$ & 0.94 & 0.96 \\
$\mathrm{~N}_{\text {min2 }}$ & Spherical & 0.87 & 72 & 0.95 & 0.66 \\
$\mathrm{~N}_{\text {min3 }}$ & Spherical & 1.00 & 100 & 0.92 & 0.93 \\
\hline
\end{tabular}

Note: $\mathrm{n}=150$; lag class interval $=10 \mathrm{~m}$; active lag distance $=90 \mathrm{~m}$; number of pairs per variogram class interval $=40$ to 361 .

* Proportion of the sill $\left(\mathrm{C}_{0}+\mathrm{C}\right)$ explained by spatially structured variance $(\mathrm{C})$ where $\mathrm{C}_{0}$ is the nugget variance.

** For exponential model, the effective range is defined as $3 \mathrm{~A}_{0}$, the distance at which the sill is within $5 \%$ of the asymptote.

scription, is inadequate here to guide variable $\mathrm{N}$ fertilizer application of since it did not show a defined spatial structure.

\section{Corn Grain and N Uptake Response to N Fertilizer}

$\mathrm{N}$ fertilizer significantly $(p<0.001)$ increased corn grain yield (Table 3$)$. Averaged across all soil types, grain yield was $4.00 \mathrm{Mg} \mathrm{ha}^{-1}$ in control areas $(0 \mathrm{~N})$ and $6.65 \mathrm{Mg} \mathrm{ha}^{-1}$ where $250 \mathrm{~kg} \mathrm{~N} \mathrm{ha}^{-1}$ was applied. A moderate corn grain yield variability $(\mathrm{CV}=26.7 \%)$ was observed with a minimum of $1.4 \mathrm{Mg} \mathrm{ha}^{-1}$ and a maximum of $8.7 \mathrm{Mg} \mathrm{ha}^{-1}$. The highest average yield (6.48 $\mathrm{Mg} \mathrm{ha}^{-1}$ ) was observed on the fine sandy loam and the lowest one on the clay $\left(4.86 \mathrm{Mg} \mathrm{ha}^{-1}\right)$. The corn grain $\mathrm{N}$ uptake was also significantly affected by $\mathrm{N}$ fertilizer and the pattern of response differed between soil types. The maximum $\mathrm{N}$ uptake $(83 \mathrm{~kg} \mathrm{~N}$ $\mathrm{ha}^{-1}$ ) was obtained with $250 \mathrm{~kg} \mathrm{~N} \mathrm{ha}^{-1}$ on the clay but with only $150 \mathrm{~kg} \mathrm{~N} \mathrm{ha}^{-1}$ on the clay loam and fine sandy loam. For the 50 $\mathrm{kg} \mathrm{N} \mathrm{ha}{ }^{-1}$ rate, the ANM (as estimated by the $\mathrm{N}$ uptake from the control treatment and the difference between fall and spring $\mathrm{N}$ content in the 0 - to $0.2-\mathrm{m}$ layer) was significantly larger in the clay loam $\left(122 \mathrm{~kg} \mathrm{ha}^{-1}\right)$ than in the fine sandy loam $\left(80 \mathrm{~kg} \mathrm{ha}^{-1}\right)$ or clay $\left(64 \mathrm{~kg} \mathrm{ha}^{-1}\right)$. This suggests that the contribution of clay content to ANM as suggested from incubation studies[10] did not hold under the climatic conditions of 2000. These ANM are however in the same range as the $\mathrm{N}_{\min }$. The clay area has a larger average OM content $\left(34.2 \mathrm{~g} \mathrm{~kg}^{-1}\right)$ than the loamy soils $(27.2 \mathrm{~g}$ $\mathrm{kg}^{-1}$ ). It should theoretically have a higher ANM than coarser soils. These low ANM for the clay area are probably related to the wet soil conditions that may have restricted $\mathrm{N}$ mineralization[3] or enhanced $\mathrm{N}$ losses due to leaching and/or denitrifica- 
tion. Braum et al.[24] indicated that the relationship between $\mathrm{N}$ fertilizer response and soil attributes was weather-dependent.

\section{The $\mathrm{N}_{\max }$ as Predicted by $\mathbf{N}$ Mineralization Indicators}

The estimated $\mathrm{N}_{\max }$ varied with $\mathrm{N}_{\min }$ indicators and ranged between 159 and $250 \mathrm{~kg} \mathrm{ha}^{-1}$ (Table 4). The highest $\mathrm{N}_{\max }$ was observed in the clay area that had also the lowest ANM (Table 3). The year 2000 climatic conditions may partly explain this variation. Sogbedji et al.[25] reported that economic optima $\mathrm{N}$ fertilizer for corn are strongly affected by weather especially by early season precipitation. The April-May rainfall was much larger in
$2000(249 \mathrm{~mm})$ than the last 30 -year average (153 mm). Precipitation pattern for the remainder of the growing season was, however, comparable to the average of the last 30 years. Denitrification and $\mathrm{N}$ leaching transfers increase under these very wet spring conditions [26] and therefore may have resulted in larger $\mathrm{N}_{\max }$ on clay than in better drained coarser soils. Waterlogging is also known to limit $\mathrm{N}_{\min }$ from the soil organic $\mathrm{N}$ pool and nitrification[3]. These results also indicate that the locally recommended $170 \mathrm{~kg} \mathrm{~N} \mathrm{ha}{ }^{-1}$ application would have been adequate to reach maximum yield on the loamy soils but not on the clay. The $\mathrm{N}_{\max }$ calculated over the whole field was very close to the recommended rate for corn[12].

The $\mathrm{R}^{2}$ and $\mathrm{SE}$ of the quadratic model used to determine $\mathrm{N}_{\max }$ varied among textural soil groups and $\mathrm{N}_{\min }$ indicators

TABLE 3

Corn Grain Yield, $\mathrm{N}$ Uptake, ANM, and $\mathrm{N}_{\text {rec }}$ as Estimated for the Three Soil Classes (C = Clay; CL = Clay Loam; FSL = Fine Sandy Loam)

\begin{tabular}{|c|c|c|c|c|c|c|c|c|c|c|c|c|}
\hline \multirow{2}{*}{$\begin{array}{c}\text { N Rates } \\
\left(\text { kg N ha }^{-1}\right)\end{array}$} & \multicolumn{3}{|c|}{$\begin{array}{c}\text { Corn Grain Yield } \\
\left(\mathrm{Mg} \mathrm{ha}^{-1}\right)\end{array}$} & \multicolumn{3}{|c|}{$\begin{array}{c}\text { Corn N Uptake } \\
\left(\mathrm{kg} \mathrm{ha}^{-1}\right)\end{array}$} & \multicolumn{3}{|c|}{$\begin{array}{c}\text { ANM } \\
\left(\mathrm{kg} \mathrm{ha}^{-1}\right)\end{array}$} & \multicolumn{3}{|c|}{$\mathbf{N}_{\text {rec }, \%}$} \\
\hline & C & CL & FSL & C & CL & FSL & C & CL & FSL & C & CL & FSL \\
\hline 0 & 3.65 & 3.72 & 4.86 & 42 & 36 & 50 & 93 & 140 & 135 & - & - & - \\
\hline 50 & 4.31 & 6.09 & 6.36 & 46 & 66 & 70 & 64 & 122 & 80 & 8.0 & 60.0 & 40.0 \\
\hline 100 & 4.98 & 6.09 & 6.82 & 57 & 64 & 78 & 33 & 43 & 57 & 15.0 & 28.0 & 28.0 \\
\hline 150 & 5.42 & 6.70 & 6.89 & 55 & 82 & 86 & 5 & -8 & 18 & 8.7 & 30.7 & 24.0 \\
\hline 200 & 4.40 & 6.36 & 6.83 & 51 & 71 & 81 & -61 & -79 & 2 & 4.5 & 17.5 & 15.5 \\
\hline 250 & 6.42 & 6.42 & 7.10 & 83 & 75 & 85 & -69 & -59 & -90 & 16.4 & 15.6 & 14.0 \\
\hline Means & 4.86 & 5.90 & 6.48 & 56 & 66 & 75 & 11 & 27 & 34 & 10.5 & 30.4 & 24.3 \\
\hline
\end{tabular}

Source of variation

$\begin{array}{lcccc}\text { Replicates } & 2.19 & 0.74^{*} & 23.17^{* * *} & 3.03^{* *} \\ \text { N rates } & 19.49^{* * *} & 4.33^{* * *} & 145.53^{* * *} & 2.27^{* *} \\ \text { Soil class } & 26.74^{* * *} & 2.83^{* * *} & 10.25^{* *} & 3.78^{* *} \\ \text { Error } & 0.63 & 322.09 & 2538.18 & 725.36\end{array}$

${ }^{*},{ }^{* *},{ }^{* * *}$ : significant at $p<0.05, p<0.01, p<0.001$, respectively.

TABLE 4

Fertilizer $N$ Rate to Reach $\mathrm{N}_{\max }, \mathrm{R}^{2}$, and $\mathrm{SE}$ as Calculated by Quadratic Model using Four N Mineralization Indicators

\begin{tabular}{|c|c|c|c|c|c|c|c|c|c|c|c|c|c|c|c|}
\hline & \multicolumn{3}{|c|}{ Soil Classes* } & \multicolumn{3}{|c|}{$\mathrm{OM}\left(\mathrm{g} \mathrm{kg}^{-1}\right)^{\star \star}$} & \multicolumn{3}{|c|}{$\mathrm{N}_{\min 1}\left(\mathrm{~kg} \mathrm{ha}^{-1}\right)^{\star \star \star}$} & \multicolumn{3}{|c|}{$\mathrm{N}_{\min 2}\left(\mathrm{~kg} \mathrm{ha}^{-1}\right)^{\dagger}$} & \multicolumn{3}{|c|}{$\mathbf{N}_{\min 3}\left(\mathbf{k g ~ h a}^{-1}\right)^{\dagger}$} \\
\hline & $\mathbf{N}_{\max }$ & $\mathbf{R}^{2}$ & SE & $\mathbf{N}_{\max }$ & $\mathbf{R}^{2}$ & SE & $\mathbf{N}_{\max }$ & $\mathbf{R}^{2}$ & SE & $\mathbf{N}_{\max }$ & $\mathbf{R}^{2}$ & SE & $\mathbf{N}_{\max }$ & $\mathbf{R}^{2}$ & SE \\
\hline C & 250 & 0.64 & 0.664 & 227 & 0.60 & 0.594 & 187 & 0.89 & 0.090 & 226 & 0.61 & 0.594 & 166 & 0.68 & 0.488 \\
\hline CL & 192 & 0.87 & 0.311 & 176 & 0.88 & 1.392 & 159 & 0.85 & 0.411 & 171 & 0.87 & 0.357 & 185 & 0.90 & 0.243 \\
\hline FSL & 173 & 0.91 & 0.130 & 250 & 0.53 & 1.626 & 250 & 0.58 & 0.859 & 250 & 0.53 & 1.390 & 250 & 0.55 & 0.879 \\
\hline Global & 180 & 0.87 & 0.31 & 180 & 0.87 & 0.310 & 180 & 0.87 & 0.310 & 180 & 0.87 & 0.310 & 180 & 0.87 & 0.310 \\
\hline
\end{tabular}

* $\quad$ C = clay; CL - clay loam; FSL - fine sandy loam.

** $1=\mathrm{OM}<25 ; 2=25<\mathrm{OM}<35 ; 3=\mathrm{OM}>35$.

*** $1=<50 ; 2=50$ to $100 ; 3=>100$.

$+\quad 1=<70 ; 2=70$ to $90 ; 3=>90$

Global: all data; $\mathrm{N}_{\min 1}=4.00+0.29 \mathrm{OM}+0.22$ clay; $\mathrm{N}_{\min 2}=22.16+0.91 \mathrm{OM} ; \mathrm{N}_{\min 3}=18.62+1.46 \mathrm{OM}+0.10$ clay; $\mathrm{N}_{\min 1}, \mathrm{~N}_{\min 2}$, and $\mathrm{N}_{\min 3}$ are calculated according to Simard and N'dayegamiye[10]. 
(Table 4). The $\mathrm{R}^{2}$ ranged from 0.53 to 0.91 and the $\mathrm{SE}$ from 0.13 to 1.62 . The highest $\mathrm{R}^{2}$ and the lowest $\mathrm{SE}$ were obtained on the fine sandy loam area. Based on these two parameters, $\mathrm{N}_{\max }$ was $250 \mathrm{~kg} \mathrm{~N} \mathrm{ha}^{-1}$ on clay, $192 \mathrm{~kg} \mathrm{~N} \mathrm{ha}^{-1}$ on clay loam, and $173 \mathrm{~kg} \mathrm{~N} \mathrm{ha}^{-1}$ on the fine sandy loam. The $\mathrm{N}_{\min 1}$ was the best $\mathrm{N}_{\text {min }}$ indicator to determine $\mathrm{N}_{\max }$ with on average $\mathrm{R}^{2}$ of 0.77 and a SE of 0.45 .

\section{Fertilizer N Recovery and Residual Soil N}

The $\mathrm{N}$ fertilizer recovery coefficient in grain $\left(\mathrm{N}_{\mathrm{rec}}\right)$ was affected by soil texture and $\mathrm{N}$ fertilizer rates. Averaged across $\mathrm{N}$ rates, it was $10.5 \%$ in the clay, $30.4 \%$ in the clay loam, and $24.3 \%$ in the fine sandy loam area (Table 3 ). These values are lower than in previous studies[4,5]. The $\mathrm{N}_{\text {rec }}$ was inversely proportional to fertilizer $\mathrm{N}$ rates on the clay loam and fine sandy loam areas but not related to it in the clay area. Wet soil conditions may explain the low recovery of ANM on the clay soil that resulted in a higher $\mathrm{N}_{\max }$ than in the other two areas. The residual soil $\mathrm{N}$ was not significantly affected by the $\mathrm{N}$ fertilizer treatments and the average residual $\mathrm{N}$ in the 0 - to $0.2-\mathrm{m}$ layer was $81 \mathrm{mg} \mathrm{kg}^{-1}$ (data not shown). The absence of difference in fall soil residual $\mathrm{N}$ between fertilizer rates confirm that care should be taken not to overfertilize these soils since any excessive $\mathrm{N}$ may be transferred from the soil profile to the adjacent environment as it was not found as fall residual soil $\mathrm{N}$.

\section{CONCLUSIONS}

The prediction of $\mathrm{N}_{\min }$ involves the measurement of biological and physical processes. This is a very difficult task. Indicators of $\mathrm{N}_{\text {min }}$ based on soil OM and clay contents showed a spatial structure in the studied field but soil $\mathrm{NO}_{3}{ }^{-}$content did not. The corn grain yield, grain $\mathrm{N}$ uptake, fertilizer response, and $\mathrm{N}$ recovery were significantly different between areas of contrasting soil texture. Conversely, the fall residual $\mathrm{N}$ was not affected by $\mathrm{N}$ inputs or textural class. The $\mathrm{N}_{\max }$ was larger on the clay than in other soils presumably because of low apparent $\mathrm{N}_{\min }$ and fertilizer $\mathrm{N}_{\text {rec }}$. Although the results of the present study may be specific to the soil and climatic conditions, they suggest that management units based on soil texture class would help the management of fertilizer $\mathrm{N}$ in corn production on these poorly drained soils. This would increase economical benefits of $\mathrm{N}$ application and reduce the potential transfer of $\mathrm{N}$ to the atmosphere and to surface and ground waters.

\section{ACKNOWLEDGMENTS}

This study is funded by Nutrite Inc., La Ferme Promarc, Innotag Inc., and Agriculture and Agri-Food Canada through a matching investment initiative program. The assistance of Guy Forand, Christian Beaudry, Alain Larouche, Mario Deschenes, Nicolas Samson, and Lucie Grenon is greatly appreciated.

\section{REFERENCES}

1. Groffman, P.M. (1997) Ecological constraints on the ability of precision agriculture to improve the environmental performance of agricultural production systems. In Precision Agriculture: Spatial and Temporal Variability of Environmental Quality. Lake, J.V., Bock, G.R., and Goode, J.M. Eds. CIBA Foundation Symposium 210. John Wiley \& Sons, Chicester, U.K. pp. 52-67.

2. Cambardella, C.A., Moorman, T.B., Novak, J.M., Parkin, T.B., Karlen, D.L., Turco, R.F., and Konopka, A.E. (1994) Field-scale variability of soil properties in central Iowa soils. Soil Sci. Soc. Am. J. 58, 1501-1511.

3. Jarvis, S.C., Stockdale, E.A., Shepherd, M.A., and Powlson, D.S. (1996) Nitrogen mineralization in temperate agricultural soils: processes and measurement. Adv. Agron. 57, 187-235.

4. Isfan, D., Zizka, J., D’Avignon, A., and Deschenes, M. (1995) Relationship between nitrogen rate, plant nitrogen concentration, yield and residual soil nitrate-nitrogen in silage corn. Commun. Soil Sci. Plant Anal. 26, 2531-2557.

5. Tran, T.S., Giroux, M., and Cescas, M.P. (1997) Utilisation de l'engrais marqué au ${ }^{15} \mathrm{~N}$ par le maïs selon les modes d'application et les doses d'azote. Can. J. Soil Sci. 77, 9-19.

6. Painchaud, J. (1997) Substantial progress was made in Québec's water quality. Environ. Sci. Eng. 10, 34-37.

7. Macdonald, K.B. (2000). Risk of water contamination by nitrogen. In Environmental Sustainability of Canadian Agriculture. McRae, T., Smith, C.A.S., and Gregorich, L.J., Eds. Report of the Agri-Environmental Indicator Project. Agriculture and AgriFood Canada, Ottawa, ON. pp. 117-123.

8. Simard, R.R. and N'dayegamiye, A. (1993) Nitrogen mineralization potential of meadow soils. Can. J. Soil Sci. 73, 27-38.

9. Nolin, M.C., Guertin, S.P., and Wang, C. (1996) Within-field variability of soil nutrients and corn yield in a Montreal Lowlands clay soil. In Proceedings of the $3^{\text {rd }}$ Conference on Precision Agriculture. Robert, P.C., Rust, R.H., and Larson, W.E., Eds. ASA-CSSA-SSSA, Madison, WI. pp. 257-270.

10. Nolin, M.C., Simard, R.R., Cambouris, A.N., and Beauchemin, S. (1999) Specific variability of P status and sorption characteristics in clay soils of the St-Lawrence lowlands. In Proceedings of the $4^{\text {th }}$ Conference on Precision Agriculture. Robert, P.C., Rust, R.H., and Larson, W.E., Eds. ASA-CSSA-SSSA, Madison, WI. pp. 395-406.

11. Bongiovani, R. and Lowenberg-De Boer, J. (2000) Nitrogen management in corn using site-specific crop response estimates from a spatial regression model. In Proceedings of the $5^{\text {th }}$ International Conference on Precision Agriculture. ASA-CSSA-SSSA, Madison, WI. [cd-rom]

12. Conseil des Productions Végétales du Québec. (2000) Grilles de référence en fertilisation. AGDEX 540. Québec, Canada.

13. Ontario Ministry of Agriculture and Rural Affairs. (1998) Soil Fertility Handbook. Queens Printer for Ontario, Toronto, ON. $169 \mathrm{p}$.

14. Kachanoski, R.G. and Fairchild, G.L. (1996) Field scale fertilizer recommendations: the spatial scaling problem. Can. J. Soil Sci. 76, 1-6.

15. Bouma, J. (1999) Precision agriculture: a unique tool to unify production and environmental requirement in agriculture. In Proceedings of the $4^{\text {th }}$ Conference on Precision Agriculture. Robert, P.C., Rust, R.H., and Larson, W.E., Eds. ASA-CSSA-SSSA, Madison, WI. pp. 595-601.

16. Tiessen, H. and Moir, J.O. (1993) Total and organic carbon. In Soil Sampling and Methods of Analysis. Carter, M.R., Ed. Lewis Publishers, Boca Raton, FL. pp. 187-199. 
17. Sheldrick, B.H. and Wang, C. (1993) Particle size distribution. In Soil Sampling and Methods of Analysis. Carter, M.R., Ed. Lewis Publishers, Boca Raton, FL. pp. 499-511.

18. Maynard, D.G. and Kalra, Y.P. (1993) Nitrate and exchangeable ammonium nitrogen. In Soil Sampling and Methods of Analysis. Carter, M.R., Ed. Lewis Publishers, Boca Raton, FL. pp. 25-38.

19. SAS Institute Inc. (1990) SAS/STAT User's Guide. Version 6. $4^{\text {th }}$ ed. SAS Institute, Cary, NC.

20. Robertson, G.P. (2000) $\mathrm{GS}^{+}$GeoStatistics for the Environmental Sciences. Version 5.0. Gamma Design Software. Plainwell, MI. $200 \mathrm{p}$.

21. Golden Software Inc. (1999) Surfer. Contouring and 3D Surface Mapping User's Guide. Golden, CO.

22. Colwell, J.D. (1994) Estimating Fertilizer Requirements. A Quantitative Approach. CAB International, Oxford, U.K. 262 p.

23. Tabi, M., Tardif, L., Carrier, D., Laflamme, G., and Rompré, M. (1990) Inventaire des problèmes de dégradation des sols agricoles du Québec. Rapport synthèse. Gouvernement du Québec, Canada. $67 \mathrm{p}$.

24. Braum, S.M., Hinds, P., Malger, G.L., Bell, J., Mulla, D., and Robert, P.C. (1999) Terrain attributes and soil nitrogen: spatial effects on corn yield responses to nitrogen fertilization for a northern, glaciated landscape. In Proceedings of the $4^{\text {th }}$ Conference on Precision Agriculture. Robert, P.C., Rust, R.H., and
Larson, W.E., Eds. ASA-CSSA-SSSA, Madison, WI. pp. 195201.

25. Sogbedji, J.M., van Es, H.M., Klausner, S.D., Bouldin, D.R., and Cox, W.J. (2001) Spatial and temporal processes affecting nitrogen availability at the landscape scale. Soil Tillage Res. 58, $233-244$.

26. 'Franzluebbers, A.J, Hons, F.M., and Zuberer, D.A. (1995) Tillage and crop effects on seasonal soil carbon and nitrogen dynamics. Soil Sci. Soc. Am. J. 59, 1618-1624.

\section{This article should be referenced as follows:}

Simard, R.R., Ziadi, N., Nolin, M.C., Cambouris, A.N. (2001) Prediction of nitrogen responses of corn by soil nitrogen mineralization indicators. In Optimizing Nitrogen Management in Food and Energy Production and Environmental Protection: Proceedings of the 2nd International Nitrogen Conference on Science and Policy. TheScientificWorld 1(S2), 135-141.

\begin{tabular}{llr}
\hline Received: & July & 19,2001 \\
Revised: & October & 10,2001 \\
Accepted: & October & 26,2001 \\
Published: & November & 9,2001
\end{tabular}




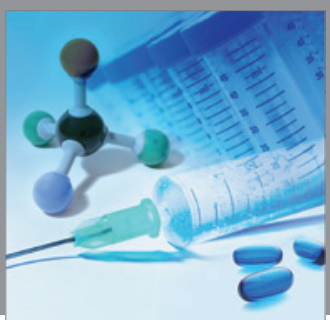

International Journal of

Medicinal Chemistry

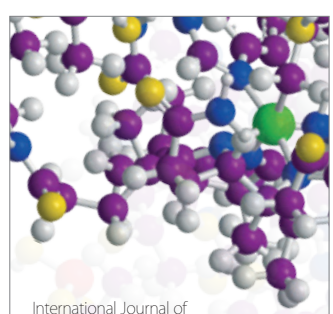

Carbohydrate Chemistry

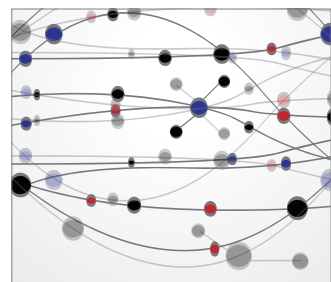

The Scientific World Journal
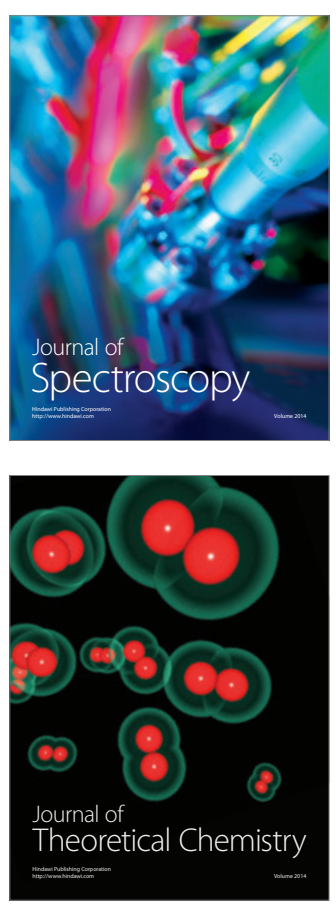
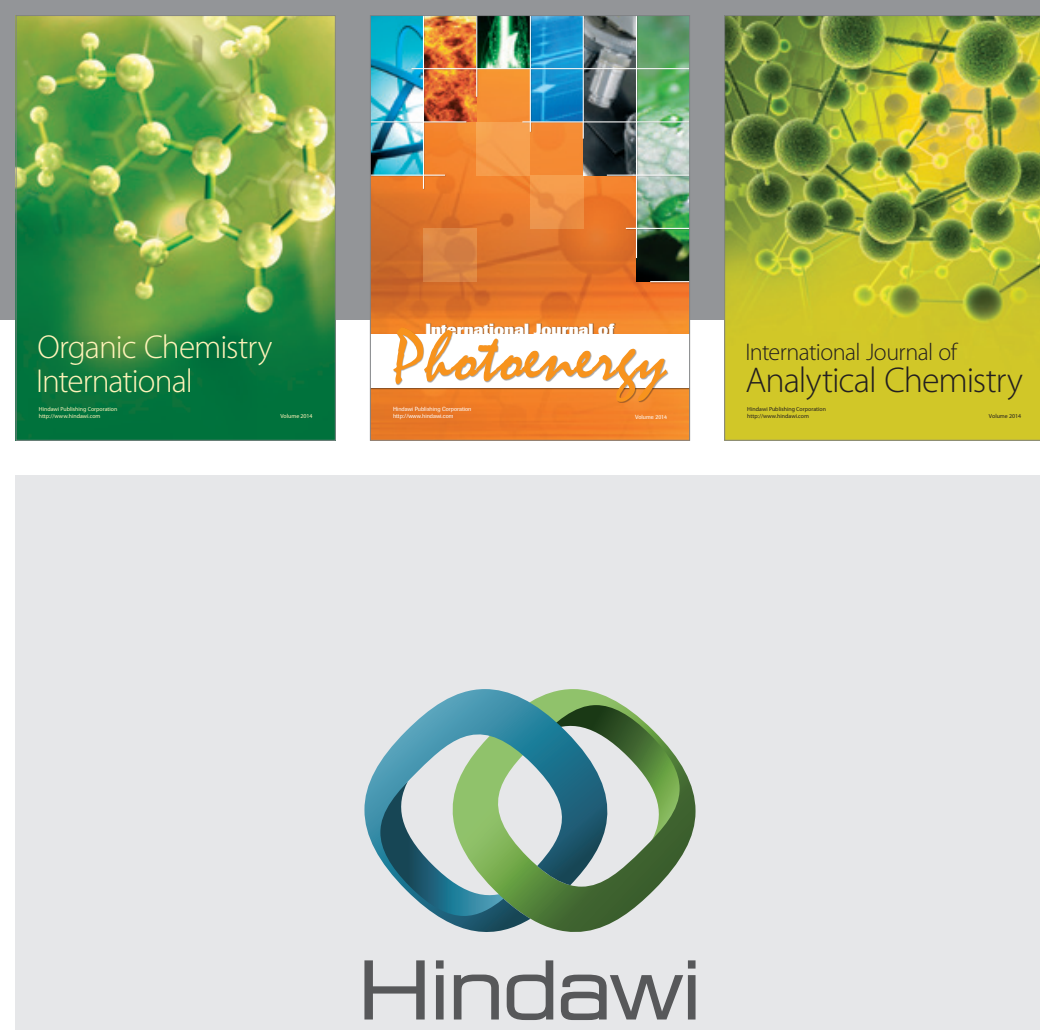

Submit your manuscripts at

http://www.hindawi.com
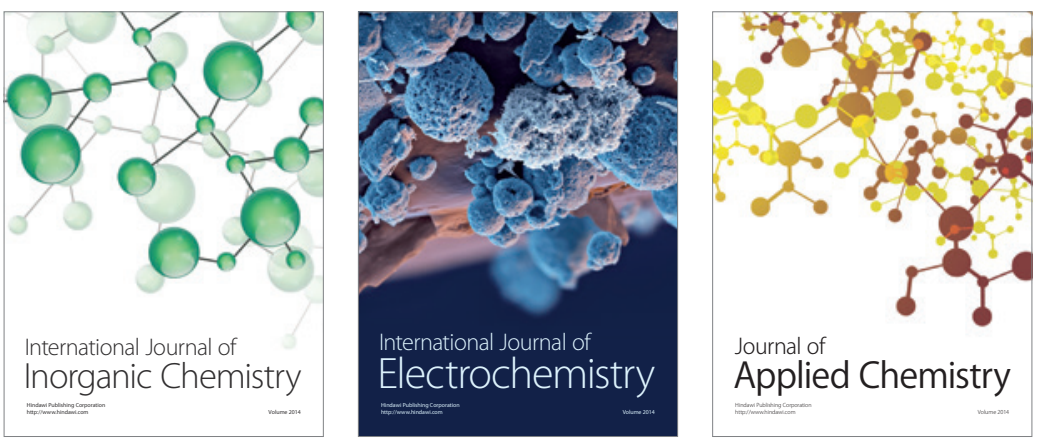

Journal of

Applied Chemistry
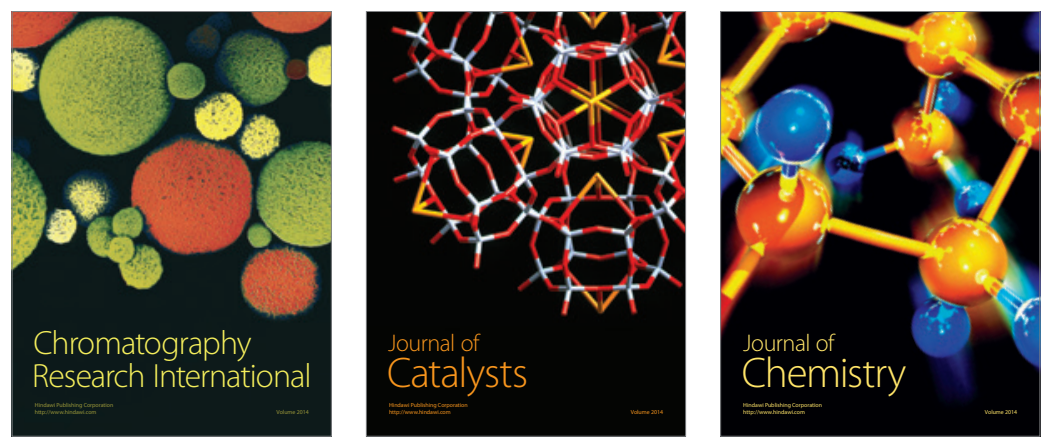
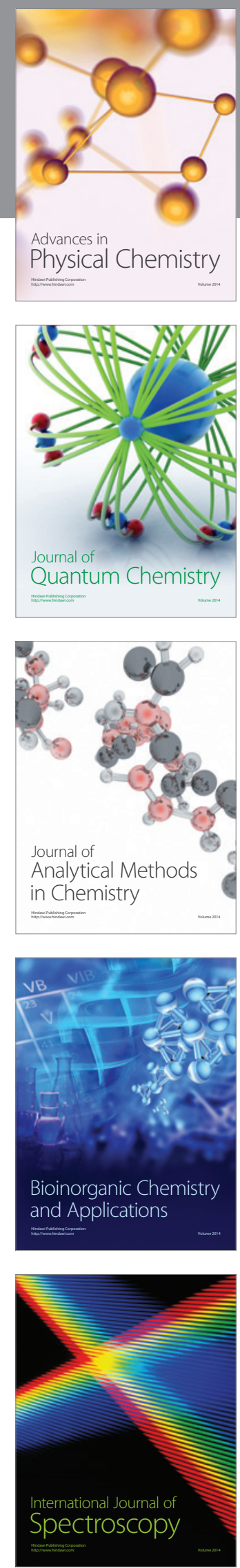